\title{
Optimization protocol for the extraction of 6-gingerol and 6-shogaol from Zingiber officinale var. rubrum Theilade and improving antioxidant and anticancer activity using response surface methodology
}

\author{
Ali Ghasemzadeh ${ }^{1 *}$, Hawa Z.E. Jaafar ${ }^{1}$ and Asmah Rahmat ${ }^{2}$
}

\begin{abstract}
Background: Analysis and extraction of plant matrices are important processes for the development, modernization, and quality control of herbal formulations. Response surface methodology is a collection of statistical and mathematical techniques that are used to optimize the range of variables in various experimental processes to reduce the number of experimental runs, cost, and time, compared to other methods.
\end{abstract}

Methods: Response surface methodology was applied for optimizing reflux extraction conditions for achieving high 6-gingerol and 6-shogaol contents, and high antioxidant activity in Zingiber officinale var. rubrum Theilade. The two-factor central composite design was employed to determine the effects of two independent variables, namely extraction temperature $\left(X_{1}: 50-80^{\circ} \mathrm{C}\right)$ and time $\left(X_{2}: 2-4 \mathrm{~h}\right)$, on the properties of the extracts. The 6-gingerol and 6-shogaol contents were measured using ultra-performance liquid chromatography. The antioxidant activity of the rhizome extracts was determined by means of the 1,1-diphenyl-2-picrylhydrazyl assay. Anticancer activity of optimized extracts against HeLa cancer cell lines was measured using MTT (3-(4,5-dimethylthiazol-2-yl)-2, 5-diphenyltetrazolium bromide) assay.

Results: Increasing the extraction temperature and time induced significant response of the variables. The optimum extraction condition for all responses was at $76.9^{\circ} \mathrm{C}$ for $3.4 \mathrm{~h}$. Under the optimum condition, the corresponding predicted response values for 6-gingerol, 6-shogaol, and the antioxidant activity were $2.89 \mathrm{mg} / \mathrm{g}$ DW, $1.85 \mathrm{mg} / \mathrm{g} \mathrm{DW}$, and $84.3 \%$, respectively. 6-gingerol and 6-shogaol were extracted under optimized condition to check the viability of the models. The values were 2.92 and $1.88 \mathrm{mg} / \mathrm{g} \mathrm{DW}$, and $84.0 \%$ for 6-gingerol, 6-shogaol, and the antioxidant activity respectively. The experimental values agreed with those predicted, thus indicating suitability of the models employed and the success of RSM in optimizing the extraction condition. With optimizing of reflux extraction anticancer activity of extracts against HeLa cancer cells enhanced about $16.8 \%$. The half inhibition concentration $\left(\mathrm{IC}_{50}\right)$ value of optimized and unoptimized extract was found at concentration of 20.9 and $38.4 \mathrm{\mu g} / \mathrm{mL}$ respectively. Optimized extract showed more distinct anticancer activities against HeLa cancer cells in a concentration of $40 \mu \mathrm{g} / \mathrm{mL}(P<0.01)$ without toxicity to normal cells.

Conclusions: The results indicated that the pharmaceutical quality of ginger could be improved significantly by optimizing of extraction process using response surface methodology.

Keywords: 6-Gingerol, 6-Shogaol, DPPH activity, Zingiber officinale var. rubrum Theilade, Response surface methodology

\footnotetext{
*Correspondence: alighasemzadeh@upm.edu.my

'Department of Crop Science, Faculty of Agriculture, Universiti Putra

Malaysia, 43400 Serdang, Selangor, Malaysia

Full list of author information is available at the end of the article
} 


\section{Background}

Herbs and natural products are precious sources of medicinal compounds and their benefits and importance for healing have been well recognized since ancient times. The characteristics and health effects of natural bioactive compounds, especially from plant sources including spices, have been extensively investigated. Phytochemicals are important compounds found in medicinal plants that are not essential for the normal functioning of the human body, but are active and exert positive effects on health or in amelioration of diseases. Many phytochemicals have been identified though a great many are yet to be identified [1]. According to a report by the World Health Organization, $80 \%$ of the population in developing countries depends on traditional medicine for their primary health care, and $85 \%$ of traditional medicine is derived from plant extracts [2]. In Malaysia, herbs and spices are generally consumed raw and fresh as vegetables (salad), especially by the Malay community. Ginger (Zingiber officinale Roscoe) is one of the most widely used spices in the world, especially in Malaysia and locally was known as Halia. Owing to its universal appeal, ginger has spread to most tropical and subtropical countries from China and India, where ginger cultivation has been prevalent, possibly since prehistoric times [3]. In ancient times, ginger was highly valued for its medicinal properties and it played an important role in primary health care in ancient India and China. Ginger contains a variety of pungent and biologically active compounds, primarily 6-gingerol, 6-shogaol, zingerone, phenolics, and flavonoids [4]. Between identified components, 6-gingerol was reported as the most abundant bioactive compound in ginger with various pharmacological effects including antioxidant, analgesic, anti-inflammatory and antipyretic properties [5-8]. The result of recent studies showed that 6-shogaol with lowest concentration in ginger represent more biologically actives compared to 6-gingerol [9-11] Dugasani et al. [12] reported 6-shogaol as a potent anti-inflammatory and antioxidant compounds in ginger. Various methods for the analysis of 6-gingerol and 6-shogaol in ginger extract have been reported [13-15] but, among these, highperformance liquid chromatography (HPLC) is most widely utilized. Extraction prior to component analysis is the main step for the recovery and isolation of bioactive phytochemicals from plant materials. Analysis and extraction of plant matrices are important processes for the development, modernization, and quality control of herbal formulations [13]. In general, the first step of complete extraction is the selection of plant parts and careful preparation of plant extracts, and a thorough review of the existing literature to learn about the most suitable protocols for a specific group of compounds or plant species. Traditionally, the extraction of 6-gingerol and 6-shogaol compounds is accomplished by reflux or Soxhlet extraction [16]. However, prolonged extraction at high temperature may degrade the 6-gingerol and 6-shogaol compounds, and involves high energy cost. Bhattarai et al. [17] recently reported that in acidic media and under high extraction temperature 6-gingerol can be degraded to 6-shogaol. Generally, the widespread use of ginger as a spice, dietary supplement, tea, cream, household remedy, as well as an ingredient of various herbal formulations, requires standardization of ginger formulations. A model for optimizing the most relevant operational parameters is required in order to achieve higher extraction yield. Response surface methodology (RSM) is a collection of statistical and mathematical technique that used to optimize the range of variables in various experimental processes with reducing the number of experimental runs, cost and time compared to other methods. Zingiber officinale var. rubrum Theilade is distributed mainly in Peninsular Malaysia, where it is known locally as halia udang, halia merah and halia bara. To the best of our knowledge, no other studies have been undertaken to optimize extraction condition of 6-gingerol and 6-shogaol from Z.officinale.var.rubrum Theilade. The aim of this study was to optimize the conditions for the extraction of a Malaysian ginger variety Zingiber officinale var. rubrum Theilade namely Halia bara to achieve high 6-gingerol and 6-shogaol contents and high antioxidant and anticancer capacity by using response surface methodology with a central composite design (CCD).

\section{Methods}

\section{Plant materials}

Z.officinale var. rubrum Theilade rhizomes were collected from Bentong, Pahang, Malaysia. The samples were identified by herbarium of department of biology, faculty science, University Putra Malaysia. Rhizomes were washed with pure water and were soaked in a Mancozeb solution $(0.3 \%)$ for $30 \mathrm{~min}$ and were cut into $3-5 \mathrm{~cm}$ pieces containing 2 to 3 buds. After cutting, all pieces were planted $6 \mathrm{~cm}$ deep into the small pots filled with about $1 \mathrm{~kg}$ peat moss. Rhizomes were grown in a glasshouse for two weeks. Afterward, seedlings with 2 or 3 leaves were transplanted into polyethylene bags filled with a soilless mixture composed of burnt rice husk and coco peat (1:1). Ginger is a semi-shade loving plant and needs shade for growth and rhizome production. Then, the plants were grown under glasshouse conditions at the glasshouse complex of Universiti Putra Malaysia (UPM) where daily irradiance was approximately $790 \mu \mathrm{mol} / \mathrm{m}^{2} / \mathrm{s}$ (light intensity in outside was $1150 \mu \mathrm{mol} / \mathrm{m}^{2} / \mathrm{s}$ ). Relative humidity was $70 \pm 5 \%$ and average temperature was $28 \pm 1{ }^{\circ} \mathrm{C}$. The plants were harvested after nine month, with the leaves, stems, and rhizomes separated. The rhizomes were shade dried and were powdered using grinder. These powdered materials were used for further analysis. 


\section{Extraction}

The optimization procedure for the extraction process focusing on the extraction temperature $\left(X_{1}: 50-80{ }^{\circ} \mathrm{C}\right)$ and extraction time $\left(X_{2}: 2-4 \mathrm{~h}\right)$ was devised based on two factor central composite design, as summarized in Table 1. Rhizomes of Z.officinale var. rubrum Theilade were harvested and washed with water and shade dried. Ten grams of dried rhizomes were extracted with absolute ethanol $(100 \mathrm{~mL})$ for $2-4 \mathrm{~h}$ at $50-80{ }^{\circ} \mathrm{C}$ using a reflux apparatus (Table 1). The ginger extracts were filtered through Whatman No.1 filter paper and kept at $-20{ }^{\circ} \mathrm{C}$ for future analysis.

\section{Ultra High Performance Liquid Chromatography (UHPLC) analysis}

The UHPLC system (Agilent, Model 1200) with Agilent $\mathrm{C}_{18}(4.6 \times 250 \mathrm{~mm}, 5 \mu \mathrm{m})$ column was used for 6 -gingerol and 6-shogaol analysis. In this system two mobile phases including: (A) water and (B) acetonitril (CAN) were used. The column temperature, flow rate and injection volume were adjusted at $48{ }^{\circ} \mathrm{C}, 1 \mathrm{~mL} / \mathrm{min}, 20 \mu \mathrm{L}$. The UV absorbance was measured at $280 \mathrm{~nm}$. To prepare the standard solution 6-gingerol and 6-shogaol (0.0625, 0.125, 0.250, 0.500 and $1 \mathrm{mg} / \mathrm{mL}$ ) were dissolved in HPLC grade methanol. The linear regression equation were calculated with $\mathrm{Y}=\mathrm{aX} \pm \mathrm{b}$, where $\mathrm{X}$ was concentration of 6-gingerol and 6-shogaol and $Y$ was the peak area of 6-gingerol and 6shogaol obtained from UHPLC. Identification of the compounds was achieved by comparison of retention times with standards, UV spectra and UV absorbance ratios after co-injection of samples and standards. System suitability requirements: Perform at least five replicate injections of 6-gingerol and 6-shogaol. The requirements of the system suitability parameters are : (1) Symmetry factor $\left(A_{s}\right)$ is not more than 1.5, (2) Percentage of relative standard deviation (RSD) of the retention time $\left(t_{r}\right)$ for 6-gingerol and 6-shogaol standards is not more than $2.0 \%$.

\section{1,1-Diphenyl-2-picrylhydrazyl (DPPH) assay}

The free radical scavenging activity of Z.officinale var. rubrum Theilade extracts were determined according to the Mensor et al. [18] with some modification. DPPH was dissolved in methanol to give final concentration of $2 \mathrm{mM}$. Following that, $1 \mathrm{~mL}$ of DPPH solution was added to different concentration of curry leaf extracts (20, 40, 6080 and $100 \mathrm{mg} / \mathrm{mL})$. The mixture was shaked

Table 1 Levels of independent variables for reflux extraction condition based on CCD

\begin{tabular}{llllll}
\hline & \multicolumn{3}{l}{ Coded } \\
\cline { 2 - 6 } Variable & -1 & 0 & 1 & Axial $(-a)$ & Axial $(+a)$ \\
\hline$X_{1}$ : extraction temperature & 50 & 65 & 80 & 47.1 & 82.8 \\
$X_{2}$ : extraction time & 2 & 3 & 4 & 1.8 & 4.1 \\
\hline
\end{tabular}

gently and incubated at $28{ }^{\circ} \mathrm{C}$ in a dark room for $40 \mathrm{~min}$. For the control, methanol was used as a blank. The absorbance of the samples was read at $517 \mathrm{~nm}$ using spectrophotometer. BHT (butylhydroxytoluene) and $\alpha-$ tocopherol, were used as positive controls. The scavenging activity was calculated using the following formula:

$$
\begin{array}{r}
\% \text { inhibition }=\left[\begin{array}{r}
(\text { absorbance of control }- \text { absorbance of sample }) \\
\div \text { absorbance of control })
\end{array}\right] \times 100
\end{array}
$$

\section{Determination of anticancer activity}

Retrieve the frozen cells from liquid nitrogen cell storage tank and thaw the cells in cyrovials rapidly. Carefully transfer the contents of the cyrovial to a centrifuge tube and add $10 \mathrm{ml}$ of pre-warmed media slowly to the cell suspension. Spin down at $1000 \mathrm{rpm}$ for $10 \mathrm{~min}$ and gently re-suspend pellet in $10 \mathrm{ml}$ fresh media into culture flask. Incubate in $37{ }^{\circ} \mathrm{C}$ humidified incubator supplemented with $5 \% \mathrm{CO}_{2}$. After $24 \mathrm{~h}$, the old medium was discard one day after seeding and adds 2-3 ml PBS to cover all surface and discard. Add 1.5-2 ml trypsining solution to cover the flask surface and leaved at room temperature for $3 \mathrm{~min}$ until most of the cells detach. Add $10 \mathrm{ml}$ of complete medium. For MTT assay add $100 \mu \mathrm{l}$ of cell into all the wells various concentrations of optimized $\left(76.9{ }^{\circ} \mathrm{C}\right.$ and $\left.3.4 \mathrm{~h}\right)$ and unoptimized $\left(80{ }^{\circ} \mathrm{C}\right.$ and $4 \mathrm{~h})$ extracts $(10,20,40,80$ and $160 \mu \mathrm{g} / \mathrm{mL})$ and incubate in $37{ }^{\circ} \mathrm{C}, 5 \% \mathrm{CO}_{2}$ incubator for $72 \mathrm{~h}$. Prepare a stock solution of $5 \mathrm{mg} / \mathrm{ml} \mathrm{MTT} \mathrm{(3-(4,5-dimethylthiazol-}$ 2-yl)-2,5-diphenyltetrazolium bromide) in Phosphate buffered saline (PBS) and add $20 \mu \mathrm{L}$ of MTT reagent to cell monolayer. Add $100 \mu \mathrm{l}$ of DMSO (Dimethyl sulfoxide) to each well and mix thoroughly by pipetting 10-20 times to dissolved the blue formazan crystals. The absorbance of samples was read at $570 \mathrm{~nm}$ using ELISA reader.

\section{Experimental design}

RSM software with central composite experimental design (3-level, 2-factorial) was used to investigate and validate extraction parameters affecting the extraction yields of 6-gingerol $\left(Y_{1}\right), 6$-shogaol $\left(Y_{2}\right)$ and antioxidant activity $\left(Y_{3}\right)$ of Z.officinale var. rubrum Theilade rhizomes extracts. In this study, 14 experiments were designed and carried out in duplicate with different range of the independent variables, reflux temperature $\left(X_{1}: 50-80{ }^{\circ} \mathrm{C}\right)$ and extraction time $\left(X_{2}: 2-4 \mathrm{~h}\right)$. In order to conduct the experimental design and the statistical analysis the Design Expert software (version 6.0) was used. Analysis of variance (ANOVA) and response surface analysis were used to determine the statistical significance of the model. The adequacy of the model was predicted through the 
ANOVA $(\mathrm{P}<0.05)$ and regression analysis $\left(\mathrm{R}^{2}\right)$. The relationship between the response and independent variables was demonstrated using response surface plot. Initially, a second-order polynomial model was set up to predict the response variables. The equation is given below:

$$
Y=b_{0}+b_{1} X_{1}+b_{2} X_{2}+b_{1}^{2} X_{1}^{2}+b_{2}^{2} X_{2}^{2}+b_{1} b_{2} X_{1} X_{2}
$$

Where $Y$ is the predicted dependent variable; $b_{0}$ is a constant that fixes the response at the central point of the experiment; $b_{1}, b_{2}, b_{1}^{2}, b_{2}^{2}$, and $b_{1} b_{2}$ are the linear, quadratic, and interaction coefficients, respectively. Graphical and numerical optimizations were performed to obtain the optimum conditions and predicted values for the response variables based on the response optimizer.

\section{Results and Discussion}

\section{Effects of extraction conditions on 6-gingerol and} 6-shogaol content

The reflux extraction was designed based on two-factor $\mathrm{CCD}$ consisting of extraction temperature $\left(X_{1}: 50-80{ }^{\circ} \mathrm{C}\right)$ and extraction time $\left(X_{2}: 2-4 \mathrm{~h}\right)$ at five levels each (Table 1$)$. The result of response surface methodology demonstrated significant $(P<0.05)$ regression relationships between the independent variables and response variables. A high content of 6-gingerol $(2.74 \mathrm{mg} / \mathrm{g} \mathrm{DW})$ in the rhizome extract was observed for treatment 3 (Table 2). The current regression analysis also indicated that more than $80 \%$ of the variations could be explained by the models. Analysis of variance for predicted extraction model of 6-gingerol implies that the model is highly significant with a good coefficient of determination $\left(R^{2}=0.97\right)$. The result indicated significant $(\mathrm{P}<0.01)$ quadratic and linear effects of the extraction temperature and time on 6-gingerol content $\left(Y_{1}\right)$. However, no interactive effect was observed for the independent variables. The predicted model obtained for $Y_{1}$ is as follows:

$$
\begin{aligned}
Y_{1}=1.53 & +0.51 X_{1}+0.25 X_{2}+0.31 X_{1} X_{2}+0.27 X_{1}^{2} \\
& +0.009233 X_{2}^{2}
\end{aligned}
$$

Lack of fit test for the model describes the variation in the data around the fitted model. If the model does not fit the data well, the value of lack of fit will be significant and then proceeding with investigation and optimization of the fitted response surface is likely to give misleading results [19]. In current study, the "Lack of Fit $F$-value" of 4.12 implies that the Lack of Fit is not significant relative to the pure error (Table 3).

The response surface plot in Fig. 1a shows the relationship between the 6-gingerol content and the extraction temperature, as well as time, illustrating that as the temperature $\left(47.1-82.8{ }^{\circ} \mathrm{C}\right)$ and time $(1.8-4 \mathrm{~h})$ increased, the 6-gingerol content increased. Upon increasing the extraction time from 2 to $4 \mathrm{~h}$ at $80{ }^{\circ} \mathrm{C}$, the 6-gingerol content increased from 1.79 to $2.74 \mathrm{mg} / \mathrm{g}$ DW.

The result of previous study demonstrated that $ß$-hydroxy keto presence in gingerols structure is a sensitive to high temperature and promotes dehydration of gingerols at high temperature [17]. The present results are consistent with observations by Bak et al. [16] who reported that when

\begin{tabular}{|c|c|c|c|c|c|c|c|c|}
\hline Treatment & $x_{1}$ & $x_{2}$ & $\begin{array}{l}\text { 6-gingerol content } \\
\text { (mg/g DW) }\end{array}$ & $\begin{array}{l}\text { Predicted content } \\
\text { of 6-gingerol }\end{array}$ & $\begin{array}{l}\text { 6-shogaol content } \\
\text { (mg/g DW) }\end{array}$ & $\begin{array}{l}\text { Predicted content } \\
\text { of 6-shogaol }\end{array}$ & $\begin{array}{l}\text { Antioxidant } \\
\text { activity \% }\end{array}$ & $\begin{array}{l}\text { Predicted content of } \\
\text { antioxidant activity \% }\end{array}$ \\
\hline 1 (c) & 65 & 3 & 1.49 & 1.52 & 1.25 & 1.20 & 68.0 & 71.0 \\
\hline 2 & 50 & 4 & 1.08 & 1.21 & 0.90 & 1.02 & 62.5 & 65.0 \\
\hline 3 & 80 & 4 & 2.74 & 2.80 & 1.59 & 1.63 & 89.0 & 83.8 \\
\hline 4 & 80 & 2 & 1.79 & 1.73 & 1.20 & 1.12 & 78.0 & 78.3 \\
\hline $5(c)$ & 65 & 3 & 1.56 & 1.52 & 1.33 & 1.24 & 69.0 & 71.0 \\
\hline $6(c)$ & 65 & 3 & 1.42 & 1.52 & 1.21 & 1.20 & 68.0 & 71.0 \\
\hline 7 & 50 & 2 & 1.38 & 1.33 & 1.04 & 1.08 & 66.0 & 60.8 \\
\hline $8(c)$ & 65 & 3 & 1.62 & 1.52 & 1.31 & 1.20 & 70.0 & 71.0 \\
\hline 9 & 82.8 & 3 & 2.55 & 2.53 & 1.32 & 1.35 & 84.0 & 85.6 \\
\hline 10 & 65 & 4.1 & 2.00 & 1.92 & 1.55 & 1.48 & 79.0 & 75.8 \\
\hline 11 & 47.1 & 3 & 1.35 & 1.28 & 1.10 & 1.05 & 66.8 & 62.6 \\
\hline $12(c)$ & 65 & 3 & 1.52 & 1.52 & 1.28 & 1.20 & 73.0 & 71.0 \\
\hline 13 & 65 & 1.8 & 1.11 & 1.19 & 0.82 & 0.97 & 66.0 & 68.0 \\
\hline $14(c)$ & 65 & 3 & 1.55 & 1.52 & 1.24 & 1.20 & 71.0 & 71.0 \\
\hline
\end{tabular}
ginger was extracted at room temperature, the 6-gingerol

Table 2 Experimental data and predicted content obtained for the dependent variables

c central point 
Table 3 Regression coefficients, $R^{2}$, adjusted $R^{2}$ and $F$-values for dependent variables

\begin{tabular}{|c|c|c|c|c|c|c|c|c|c|c|}
\hline \multirow[b]{2}{*}{ Responses } & \multirow{2}{*}{$\begin{array}{l}\text { constant } \\
\mathrm{b}_{0}\end{array}$} & \multirow{2}{*}{$\begin{array}{l}\text { linear } \\
b_{1}\end{array}$} & \multirow{2}{*}{$\begin{array}{l}\text { quadratic } \\
\mathrm{b}_{2}\end{array}$} & \multicolumn{3}{|c|}{ Interaction } & \multirow[b]{2}{*}{$R^{2}$} & \multirow[b]{2}{*}{$R^{2}$ (adjusted) } & \multirow[b]{2}{*}{ Regression (F value) } & \multirow[b]{2}{*}{ Lack of fit ( $F$ value } \\
\hline & & & & $\overline{b_{1}^{2}}$ & $b_{2}^{2}$ & $b_{12}$ & & & & \\
\hline$Y_{1}$ & 1.53 & 0.51 & 0.25 & 0.27 & 0.0092 & 0.31 & 0.97 & 0.95 & $45.91^{* *}$ & $4.12^{n . s}$ \\
\hline$Y_{2}$ & 1.2 & 0.15 & 0.12 & 0.021 & 0.024 & 0.15 & 0.93 & 0.92 & $15.58^{* *}$ & $1.39^{\mathrm{n} . \mathrm{s}}$ \\
\hline$Y_{3}$ & 71.88 & 9.22 & 2.78 & 3.16 & 1.11 & 4.63 & 0.96 & 0.94 & $15.79^{* *}$ & $1.24^{\mathrm{n.s}}$ \\
\hline
\end{tabular}

n.s non significant

$*^{*}=$ significant at $p<0.01$

content tended to decrease as the drying temperature increased up to $60{ }^{\circ} \mathrm{C}$, whereas drying at $80^{\circ} \mathrm{C}$ resulted in an increase in the 6-gingerol yield. The origin of the enhanced 6-gingerol content at $80{ }^{\circ} \mathrm{C}$ is not clear at this moment.

Analysis of variance for predicted extraction model of 6-shogaol implies that the model is highly significant with a good coefficient of determination $\left(R^{2}=0.93\right)$ (Table 3). Significant $(P<0.05)$ quadratic effects of the extraction temperature and time on the 6-shogaol content $\left(Y_{2}\right)$ were observed. The predicted model obtained for $Y_{2}$ is as follows:

$$
Y_{2}=1.20+0.15 X_{1}+0.12 X_{2}+0.15 X_{1} X_{2}
$$

The model F-value of 15.58 obtained for the 6-shogaol content implies that the model is significant, with only a $0.07 \%$ probability that such a large "model F-value" can occur owing to noise. The "Lack of Fit $F$-value" of 1.39 implies that the Lack of Fit is not significant for the predicted model (Table 3). In the current study, treatment 3 yielded a high content of 6-shogaol in the ginger extract, with a value of $1.59 \mathrm{mg} / \mathrm{g}$ DW. The predicted content of 6-shogaol for this treatment was $1.63 \mathrm{mg} / \mathrm{g} \mathrm{DW}$, which was close to the experimental value (Table 2 ). Figure $1 \mathrm{~b}$ shows the response surface relationship between the 6shogaol content and the extraction temperature and time. The obtained results were consistent with previous studies, which reported that the 6-shogaol content increased with higher drying and extraction temperatures and the lowest 6-shogaol content was achieved when the freeze-dried ginger was extracted at a low temperature $\left(30{ }^{\circ} \mathrm{C}\right)$, whereas the highest 6-shogaol content was obtained when the ginger was dried and extracted at a high temperature $\left(80{ }^{\circ} \mathrm{C}\right)$ [17]. The results demonstrate that the amount of 6-shogaol in rhizomes extract depends more strongly on the extraction temperature than the extraction time. Figure 2 shows UHPLC chromatograms of ginger ethanol extract and standards.

\section{Effects of extraction conditions on antioxidant activity}

The DPPH stable free radical method is an easy, rapid, and sensitive method for evaluation of free radical scavenging antioxidants. The results of the DPPH assay showed that the antioxidant activity for all the extracts was more than $62.5 \%$ (Table 2). The DPPH activity was particularly high for the extracts subjected to treatment $3\left(80{ }^{\circ} \mathrm{C}, 4 \mathrm{~h}\right)$, with a value of $89 \%$. On the other hand, the regression equation obtained using the antioxidant activity $\left(Y_{3}\right)$ as the response variable was also significantly $(P<0.05)$ related to the variation of the independent variables. The coefficient of determination $\left(\mathrm{R}^{2}\right)$ obtained was 0.96 (Table 3$)$. Significant $(P<0.05)$ linear and quadratic effects of the extraction temperature and time on the antioxidant capacity were
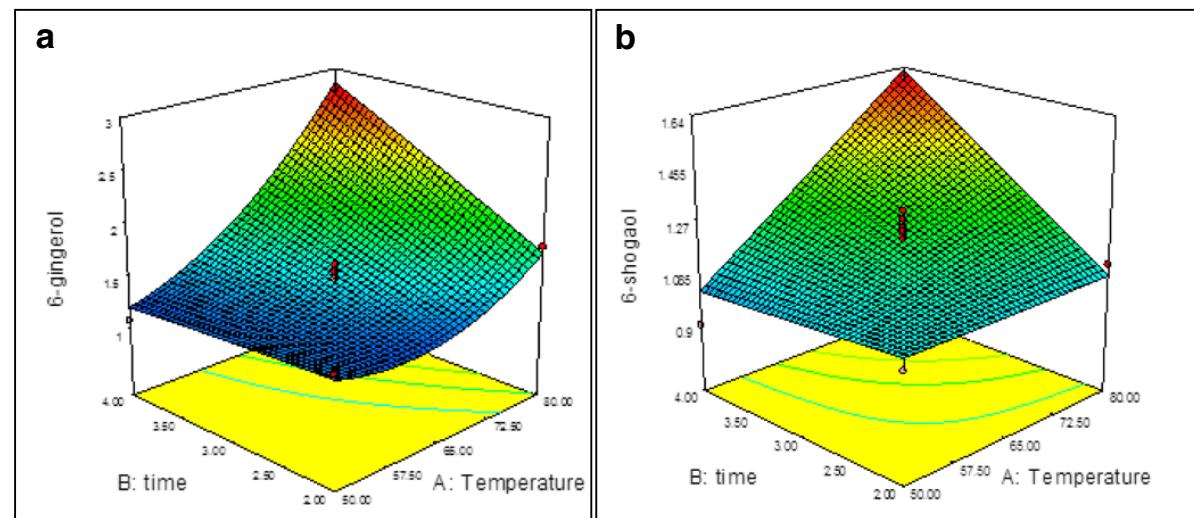

Fig. 1 Response surface plot showing the relationship between the 6-gingerol (a) and 6-shogaol (b) content with the extraction temperature and time 


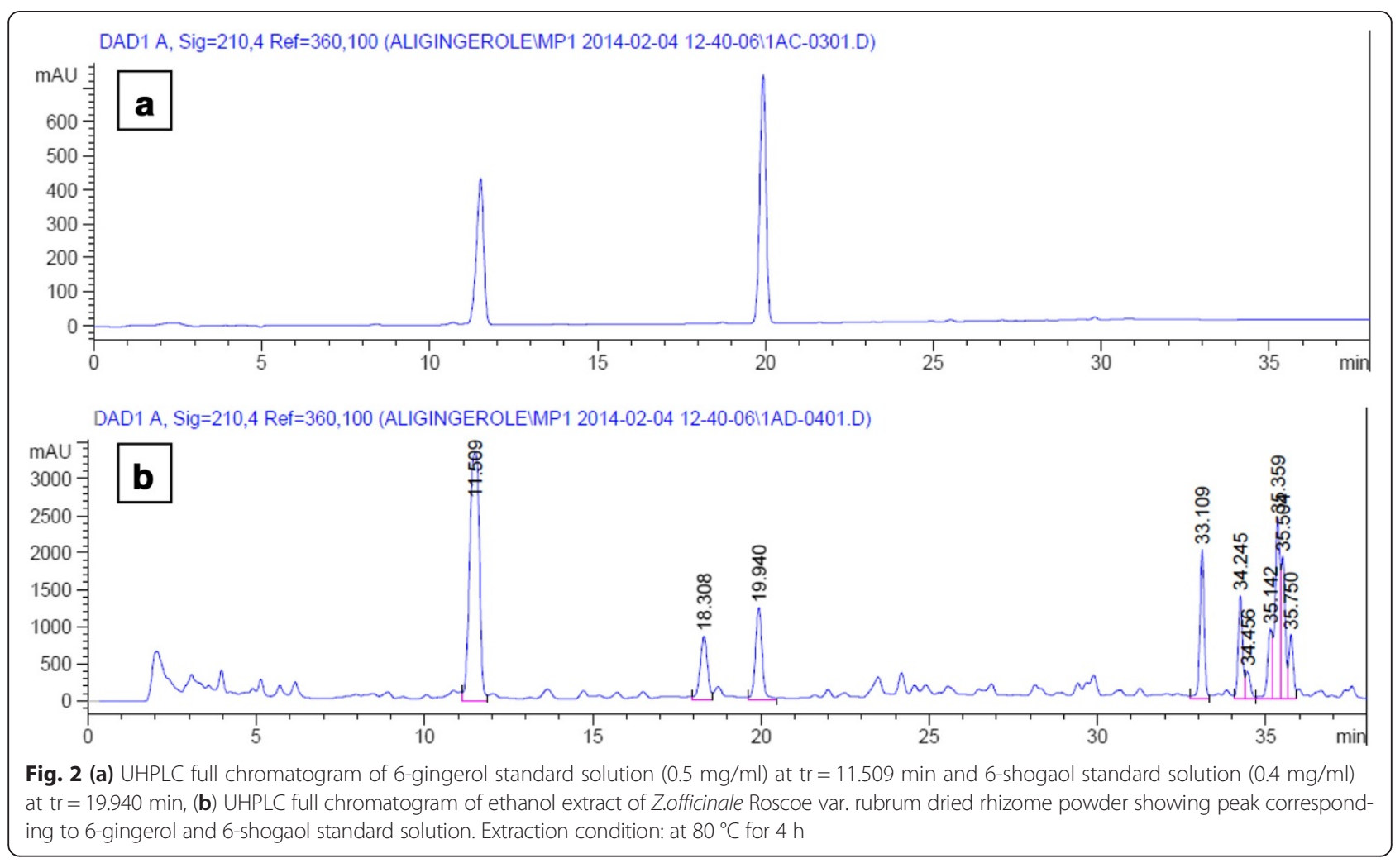

observed. The predicted model obtained for $Y_{3}$ is given below:

$$
Y_{3}=71.88+9.22 X_{1}+2.78 X_{2}+4.63 X_{1} X_{2}
$$

The model F-value of 15.79 obtained for the antioxidant activity implies that the model is significant, and the "Lack of Fit $F$-value" of 1.24 implies that the Lack of Fit is not significant for the predicted model. Figure 3 shows the response surface plot for the relationship between the antioxidant activity (DPPH) and the extraction temperature and time. An increase in the DPPH activity was observed with increasing extraction temperature and time. The increase in the DPPH activity may be due

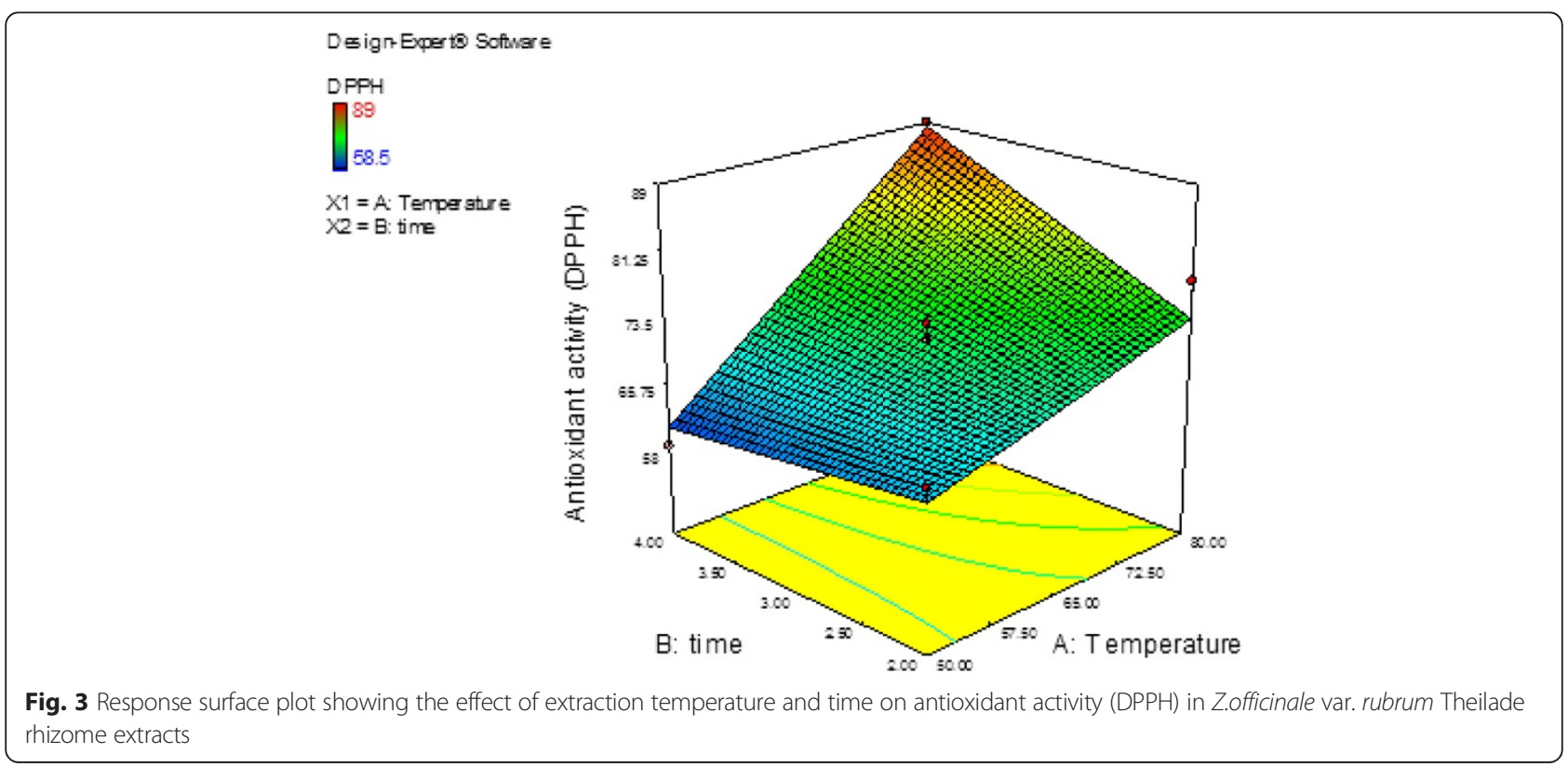


to an increase in the 6-gingerol and 6-shogaol content in the extract.

\section{Correlation between 6-gingerol, 6-shogaol and DPPH activity}

Previous studies reported that the major bioactive constituents of ginger are gingerols and shogaols with high pharmacological activities [20, 21]. Herein, a significant $(P<0.01)$ correlation between the 6-gingerol and 6shogaol content and antioxidant capacity of the ginger extract $\left(R^{2}=0.95\right.$ and 0.90$)$ was observed (Fig. 4), which is in agreement with observations by Ali et al. [22], who reported that ginger extract with a high 6-gingerol and 6-shogaol content exhibited high free radical scavenging activity. Recent study by Pawar et al. [23] and Guo et al. [24] showed that there is an strong correlation between antioxidant activity of ginger and 6-gingerol content. Herein, 6-gingerol was also found to exhibit the most potent antioxidant properties, whereas 6-shogaol was the least potent. The results obtained in the current study provide additional evidence to support the assumption that gingerols are responsible for the antioxidant activity of ginger rhizome $[25,26]$. The potent pharmaceutical quality of 6-gingerol may be attributed to its chemical structure. The predicted results were highly consistent with the experimental results obtained using the optimum extraction conditions predicted by the model, which validates the RSM model with good correlation.

\section{Optimization of response}

In order to obtain ginger extract with a high content of 6gingerol, 6-shogaol, and high antioxidant activity, the optimal reflux extraction conditions were determined based on the combination of both responses. Multiple graphical and numerical optimizations were carried out to determine the optimum level for the independent variables with desirable response goals. One optimal condition was obtained for all responses, which was reflux extraction at $76.9{ }^{\circ} \mathrm{C}$ for $3.4 \mathrm{~h}$. Under the optimum conditions, the corresponding predicted response values for 6-gingerol, 6-shogaol, and the antioxidant activity were $2.89 \mathrm{mg} / \mathrm{g}$ DW, $1.85 \mathrm{mg} / \mathrm{g}$ DW, and $84.3 \%$ respectively.
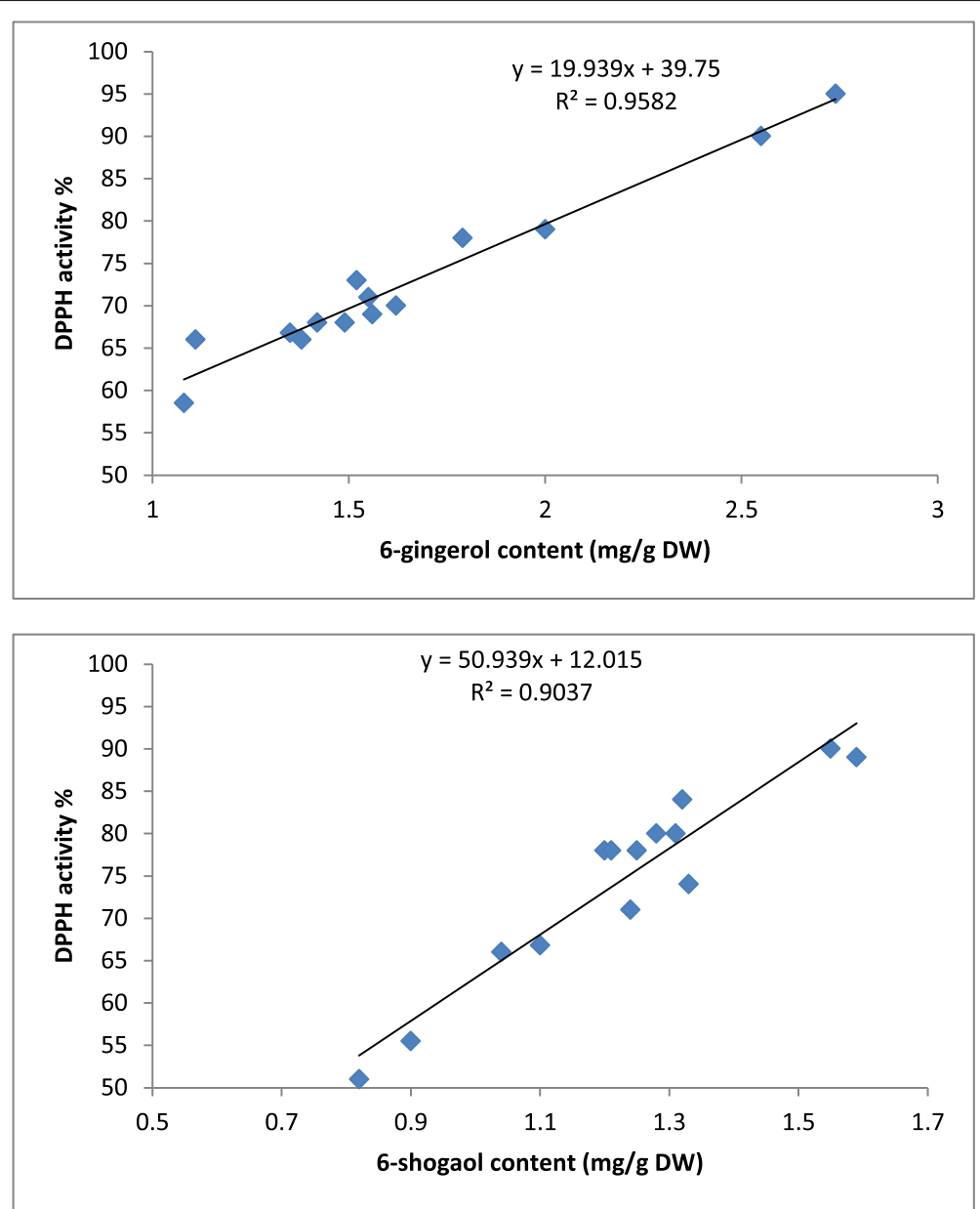

Fig. 4 Linear regression line between DPPH activity, 6-gingerol and 6-shogaol content in Z.officinale var. rubrum Theilade rhizome extracts 
Table 4 Verification of model for predicted optimum treatment conditions $\left(78.9^{\circ} \mathrm{C}\right.$ and $\left.3.8 \mathrm{~h}\right)$

\begin{tabular}{llll}
\hline & $\begin{array}{l}\text { 6-gingerol } \\
(\mathrm{mg} / \mathrm{g} \\
\mathrm{DW})\end{array}$ & $\begin{array}{l}\text { 6-shogaol } \\
(\mathrm{mg} / \mathrm{g} \\
\mathrm{DW})\end{array}$ & $\begin{array}{l}\text { Antioxidant } \\
\text { activity (\%) }\end{array}$ \\
\hline Predicted & 2.89 & 1.85 & 84.3 \\
Experimental & 2.92 & 1.88 & 84.0 \\
\hline
\end{tabular}

\section{Verification of the model}

An experiment was performed for verify the adequacy of the developed extraction model, with the predicted optimum treatment conditions $\left(76.9^{\circ} \mathrm{C}\right.$ and $3.4 \mathrm{~h}$ ). Under this condition the obtained concentration for the 6gingerol and 6-shogaol content, and the antioxidant activity were 2.92 and $1.88 \mathrm{mg} / \mathrm{g} \mathrm{DW}$, and $84.0 \%$, respectively (Table 4). The results of response surface analysis for the 6-gingerol and 6-shogaol content and antioxidant activity were verified by comparing the predicted values $(2.89 \mathrm{mg} /$ g DW, $1.85 \mathrm{mg} / \mathrm{g} \mathrm{DW}$, and $84.3 \%$ ) with the experimental values $(2.92,1.88 \mathrm{mg} / \mathrm{g} \mathrm{DW}$, and $84.0 \%)$. The obtained results from verification experiment were in consent with the predicted values, because not significant $(P>0.05)$ difference was observed between the verification experimental and the predicted values.

\section{Evaluation of anticancer activity of optimized and unoptimized ginger extract}

Optimized and unoptimized extracts of Z.officinale var. rubrum Theilade rhizome were used in order to evaluate the anticancer activity against HeLa cancer cell lines. Preliminary screening showed that rhizomes extracts exhibited a significant anticancer activity against HeLa cancer cells at concentration of $40 \mu \mathrm{g} / \mathrm{mL}$ with the inhibition rate of 51.8 and $62.3 \%$ from unoptimized and optimized extracts, respectively (Fig. 5a). HeLa cells showed $71.7 \%$ inhibition when treated with tamoxifen (positive control) at the concentration of $40 \mu \mathrm{g} / \mathrm{mL}$. Furthermore, with optimizing of reflux extraction anticancer activity of extracts were enhanced about $16.8 \%$. The half maximal inhibitory concentration $\left(\mathrm{IC}_{50}\right)$ value of optimized and unoptimized extract was found at concentration of 20.9 and $38.4 \mu \mathrm{g} / \mathrm{mL}$ respectively. The $\mathrm{IC}_{50}$ value for tamoxifen was observed at concentration of $16.4 \mu \mathrm{g} / \mathrm{mL}$. As shown in Fig. 5b the normal cells treated with the
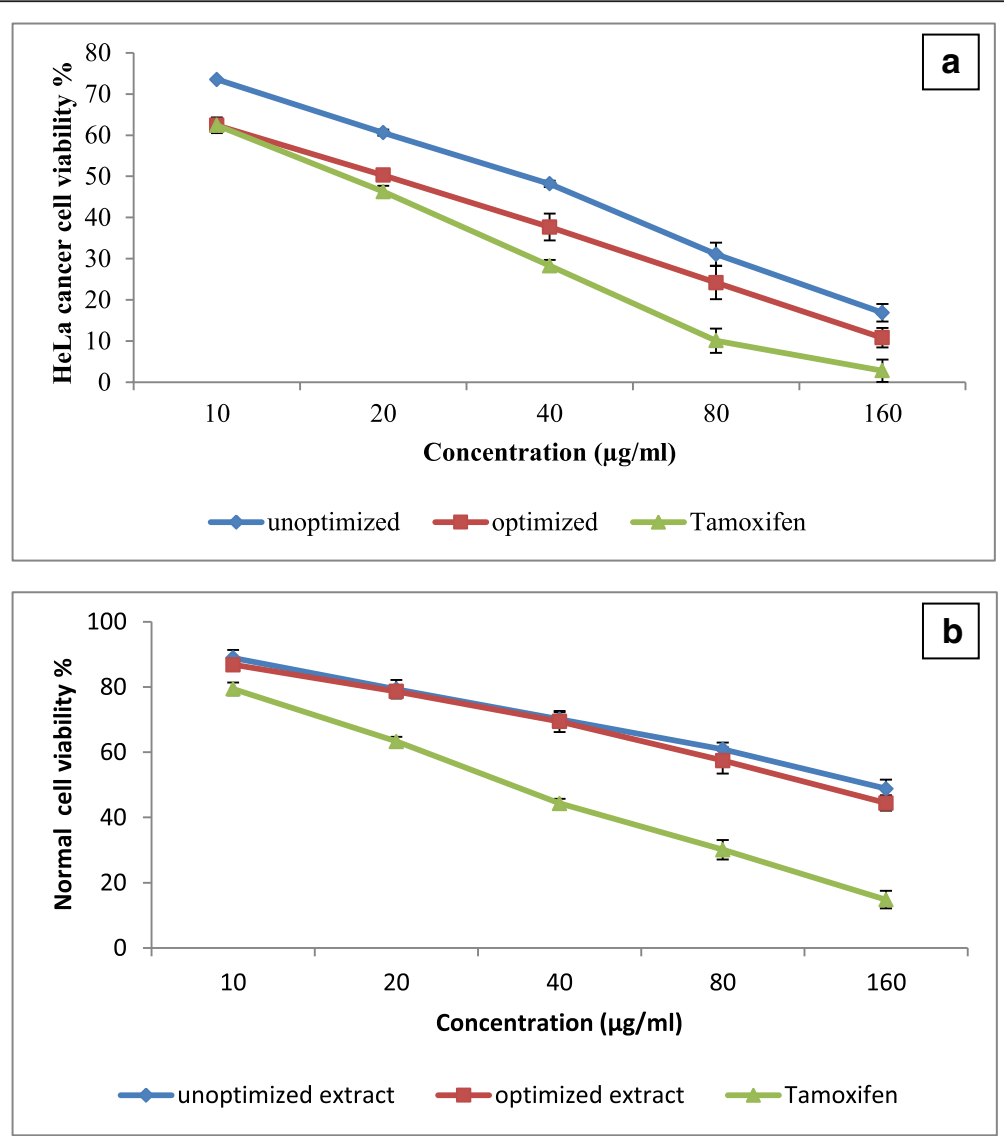

Fig. 5 Dose-dependent anticancer activity of Z.officinale var. rubrum Theilade rhizome extracts against HeLa cell line (a) and normal cell viability (b). Tamoxifen was used as a positive control. Bars represent standard error of means 
optimized and unoptimized extract of Z.officinale var. rubrum Theilade rhizome showed 70.13 and $69.43 \%$ of viability at concentration of $40 \mu \mathrm{g} / \mathrm{mL}$, respectively. According to the obtained results, optimized and unoptimized extracts showed non toxic effects at the concentrations bellow $120 \mu \mathrm{g} / \mathrm{mL}$. 6-gingerol and 6-shogale were reported as a potent anticancer compound in ginger [27-30]. The results of previous studies showed that 6-shogaol is able to kill fifty percent of Hela cancer cell line at concentration of $14.75 \mu \mathrm{M}$ [31]. Then, it could be conducted that enhancement of anticancer activity of optimized extract could be related to rising of 6-gingerol and 6-shogaol content in extract.

\section{Conclusion}

Response surface methodology was successfully implemented for the optimization of the experimental conditions for achieving high 6-gingerol and 6-shogaol content and antioxidant activity in ginger extracts. The results indicate that the extraction temperature and time affected the extraction yields of 6-gingerol and 6-shogaol significantly, and consequently the antioxidant activity of the extracts. Reflux extraction at $76.9^{\circ} \mathrm{C}$ for $3.4 \mathrm{~h}$ was determined to be the most efficient condition for the extraction of 6gingerol and 6-shogaol from Z.officinale var. rubrum Theilade rhizome to provide high antioxidant activity. Optimized extract showed a more distinct scavenging activity against the DPPH and also showed significant anticancer activities toward HeLa cancer cell lines in a concentration of $40 \mu \mathrm{g} / \mathrm{mL}$ without toxicity to normal cells.

\section{Competing interests}

The authors declare that they have no competing interests.

\section{Authors' contributions}

Study design and experimental work was by Ghasemzadeh. The first draft of the paper was written by Ghasemzadeh and reviewed by Jaafar and Rahmat. Rahmat participated in antioxidant and anticancer experiment. All authors reviewed and approved the final version.

\section{Acknowledgements}

The authors would like to thank the Ministry of Higher Education Malaysia and the Research Management Centre, Universiti Putra Malaysia (UPM) for sponsoring this work.

\section{Author details}

${ }^{1}$ Department of Crop Science, Faculty of Agriculture, Universiti Putra Malaysia, 43400 Serdang, Selangor, Malaysia. ${ }^{2}$ Department of Nutrition \& Dietetics, Faculty of Medicine \& Health Sciences, Universiti Putra Malaysia, 43400 Serdang, Selangor, Malaysia.

Received: 8 April 2015 Accepted: 11 June 2015

Published online: 30 July 2015

\section{References}

1. Boyer J, Liu RH. Apple phytochemicals and their health benefits. Nutr J. 2004;3(5):12.

2. Organization WH. WHO traditional medicine strategy 2002-2005. 2002.

3. Ghasemzadeh A, Jaafar HZ. Interactive Effect of Salicylic Acid on Some Physiological Features and Antioxidant Enzymes Activity in Ginger (Zingiber officinale Roscoe). Molecules. 2013;18(5):5965-79.
4. Ha SK, Moon E, Ju MS, Kim DH, Ryu JH, Oh MS, et al. 6-Shogaol, a ginger product, modulates neuroinflammation: A new approach to neuroprotection. Neuropharmacology. 2012;63(2):211-23.

5. Kundu JK, Surh Y-J. Molecular basis of chemoprevention with dietary phytochemicals: redox-regulated transcription factors as relevant targets. Phytochem Rev. 2009;8(2):333-47.

6. Ippoushi K, Azuma K, Ito H, Horie H, Higashio H. [6]-Gingerol inhibits nitric oxide synthesis in activated J774. 1 mouse macrophages and prevents peroxynitrite-induced oxidation and nitration reactions. Life Sci. 2003;73(26):3427-37.

7. Koo KL, Ammit AJ, Tran VH, Duke CC, Roufogalis BD. Gingerols and related analogues inhibit arachidonic acid-induced human platelet serotonin release and aggregation. Thromb Res. 2001;103(5):387-97.

8. Suekawa M, Ishige A, Yuasa K, Sudo K, Aburada M, Hosoya E. Pharmacological studies on ginger. I. Pharmacological actions of pungent constitutents, (6)-gingerol and (6)-shogaol. J Pharmacobiodyn. 1984;7(11):836-48.

9. Peng F, Tao Q, Wu X, Dou H, Spencer S, Mang C, et al. Cytotoxic, cytoprotective and antioxidant effects of isolated phenolic compounds from fresh ginger. Fitoterapia. 2012;83(3):568-85.

10. Wu H, Hsieh MC, Lo CY, Liu CB, Sang S, Ho CT, et al. 6-Shogaol is more effective than 6-gingerol and curcumin in inhibiting 12-

Otetradecanoylphorbol 13-acetate induced tumor promotion in mice. Mol Nutr Food Res. 2010;54(9):1296-306.

11. Weng CJ, Wu CF, Huang HW, Ho CT, Yen GC. Anti-invasion effects of 6-shogaol and 6-gingerol, two active components in ginger, on human hepatocarcinoma cells. Mol Nutr Food Res, 2010;54(11):1618-27.

12. Dugasani S, Pichika MR, Nadarajah VD, Balijepalli MK, Tandra S, Korlakunta JN. Comparative antioxidant and anti-inflammatory effects of [6]-gingerol, [8]-gingerol,[10]-gingerol and [6]-shogaol. J Ethnopharmacol. 2010;127(2):515-20.

13. Melianita F, Witha J, Arifin S, Kartinasari WF, Indrayanto G. Simultaneous densitometric determination of 6-gingerol, 8-gingerol, 10-gingerol, and 6-shogaol in some commercial gingers. J Liq Chromatogr Relat Technol. 2009;32(4):567-77.

14. Wang W, Li C-Y, Wen X-D, Li P, Qi L-W. Simultaneous determination of 6-gingerol, 8-gingerol, 10-gingerol and 6-shogaol in rat plasma by liquid chromatography mass spectrometry: Application to pharmacokinetics. J Chromatogr B. 2009;877(8):671-9.

15. Schwertner HA, Rios DC. High-performance liquid chromatographic analysis of 6-gingerol, 8-gingerol, 10-gingerol, and 6-shogaol in ginger-containing dietary supplements, spices, teas, and beverages. J Chromatogr B. 2007:856(1):41-7.

16. Bak M-J, Ok S, Jun M, Jeong W-S. 6-shogaol-rich extract from ginger up-regulates the antioxidant defense systems in cells and mice. Molecules. 2012;17(7):8037-55.

17. Bhattarai $\mathrm{S}$, Tran VH, Duke CC. The stability of gingerol and shogaol in aqueous solutions. J Pharm Sci. 2001;90(10):1658-64.

18. Mensor LL, Menezes FS, Leito GG, Reis AS, Santos TC, Coube CS, et al. Screening of Brazilian plant extracts for antioxidant activity by the use of DPPH free radical method. Phytother Res. 2001;15(2):127-30.

19. Noordin MY, Venkatesh VC, Sharif S, Elting S, Abdullah A. Application of response surface methodology in describing the performance of coated carbide tools when turning AISI 1045 steel. J Mater Process Technol. 2004; 145(1):46-58.

20. Lantz R, Chen G, Sarihan M, Slyom A, Jolad S, Timmermann B. The effect of extracts from ginger rhizome on inflammatory mediator production. Phytomedicine. 2007;14(2):123-8.

21. Kim DS, Kim JY. Side-chain length is important for shogaols in protecting neuronal cells from $\hat{l}^{2}$-amyloid insult. Bioorg Med Chem Lett. 2004;14(5):1287-9.

22. Ali BH, Blunden G, Tanira MO, Nemmar A. Some phytochemical, pharmacological and toxicological properties of ginger (Zingiber officinale Roscoe): A review of recent research. Food Chem Toxicol. 2008:46(2):409-20.

23. Pawar NV, Pai SR, Nimbalkar MS, Dixit GB. RP-HPLC analysis of phenolic antioxidant compound 6-gingerol from in vitro cultures of Zingiber officinale Roscoe. Plant Sci Today. 2015;2(1):24-8.

24. Guo J, Wu H, Du L, Zhang W, Yang J. Comparative Antioxidant Properties of Some Gingerols and Shogaols, and the Relationship of Their Contents with the Antioxidant Potencies of Fresh and Dried Ginger (Zingiber officinale Roscoe). J Agric Sci Technol. 2014;16(5):1063-72. 
25. Sekiwa Y, Kubota K, Kobayashi A. Isolation of novel glucosides related to gingerdiol from ginger and their antioxidative activities. J Agric Food Chem. 2000;48(2):373-7.

26. Chung W-Y, Jung Y-J, Surh Y-J, Lee S-S, Park K-K. Antioxidative and antitumor promoting effects of [6]-paradol and its homologs. Mutat Res/ Genet Toxicol Environ Mutagen. 2001;496(1):199-206.

27. Liu Q, Peng Y-B, Zhou P, Qi L-W, Zhang M, Gao N, et al. 6-Shogaol induces apoptosis in human leukemia cells through a process involving caspase-mediated cleavage of elF2a. Mol Cancer. 2013;12(1):135.

28. Tan BS, Kang O, Mai CW, Tiong KH, Khoo AS-B, Pichika MR, et al. 6-Shogaol inhibits breast and colon cancer cell proliferation through activation of peroxisomal proliferator activated receptor (PPAR). Cancer Lett. 2013;336(1):127-39.

29. Surh Y-J. Anti-tumor promoting potential of selected spice ingredients with antioxidative and anti-inflammatory activities: a short review. Food Chem Toxicol. 2002:40(8):1091-7.

30. Lee HS, Seo EY, Kang NE, Kim WK. [6]-Gingerol inhibits metastasis of MDA-MB-231 human breast cancer cells. J Nutr Biochem. 2008;19(5):313-9.

31. Liu Q, Peng Y-B, Qi L-W, Cheng X-L, Xu X-J, Liu L-L, et al. The cytotoxicity mechanism of 6-Shogaol-treated HeLa human cervical cancer cells revealed by label-free shotgun proteomics and bioinformatics analysis. Evidence-Based Complementary Altern Med 2012;2012:278652

\section{Submit your next manuscript to BioMed Central and take full advantage of:}

- Convenient online submission

- Thorough peer review

- No space constraints or color figure charges

- Immediate publication on acceptance

- Inclusion in PubMed, CAS, Scopus and Google Scholar

- Research which is freely available for redistribution 